\title{
Comparison between Hydrodistillation with Steam Explosion and Conventional Hydrodistillation in Kaffir Lime Oil Extraction
}

\author{
Yustina Wuri Wulandari ${ }^{1,3}$, Purnama Darmadji ${ }^{1}$, Chairil Anwar ${ }^{2}$, S. Supriyadi ${ }^{* 1}$ \\ ${ }^{1}$ Department of Food Science and Technology, Faculty of Agricultural Technology, Universitas Gadjah Mada, \\ Jl. Flora No. 1, Bulaksumur, Depok, Sleman, Yogyakarta 55281, Indonesia \\ ${ }^{2}$ Department of Chemistry, Faculty of Mathematics and Natural Science, Universitas Gadjah Mada, \\ Jl. Sekip Utara, Bulaksumur, Depok, Sleman, Yogyakarta 55281, Indonesia \\ ${ }^{3}$ Department of Agriculture Product Technology, Faculty of Industrial and Food Technology, Slamet Riyadi University, \\ Jl. Sumpah Pemuda no.18, Surakarta 57136, Indonesia \\ *Email: suprif248@ugm.ac.id; wuri.wulandari@unisri.ac.id
}

Submitted: September 2, 2018; Acceptance: August 16, 2019

\begin{abstract}
Steam explosion was proposed as a pretreatment method to accelerate the hydrodistillation (SE-HD) of kaffir lime leaves. This research aimed to compare SE-HD and conventional hydrodistillation (HD) in terms of extraction yield, extraction time, chemical composition, and essential oil quality. The extraction of kaffir lime oil with SE-HD was superior to HD with regard to extraction time (35 min. vs $120 \mathrm{~min}$.) and extraction yield (1.386\% vs $1.182 \%$ ). The chemical composition and the quality of the extracted essential oil from both methods were quite similar, indicating the absence of adverse influence from the application of steam explosion as pretreatment. Therefore, SE-HD was a fast and an energy-saving method for extracting essential oil from kaffir lime leaves.
\end{abstract}

Keywords: Essential oil; hydrodistillation; kaffir lime leaves; steam explosion

\section{INTRODUCTION}

Kaffir lime (Citrus hystrix. DC), from the Citrus family, is a type of lime fruit with a very strong fragrance native to Asia, especially the tropical regions (Butryee et al., 2009). The leaves can be used fresh or dried and stored at freezing temperature. The leaves impart an aromatic, strong, unique, spicy flavor in many dishes. Citronellal is dominant compound in kaffir lime leaf oil (Kawiji et al., 2016). They are widely used as a condiment in various Thai cuisine like Tom yum (Siripongvutikorn et al., 2005). In Javanese, they are used to prepare different spicy curry dishes of fish and chicken, as well as barbeques. Kaffir lime leaf oil possesses some important bioactive compounds, such as antioxidant, antileukemic (Chueahongthong et al., 2011), antitussive, antihemorrhagic, and antibacterial properties, skin-conditioning agents, and antioxidative stress properties (Waikedre et al., 2010). Therefore, kaffir lime essential oils are a potential flavoring ingredient in food, perfumery, and cosmetic industries.
Thirty-eight constituents are identified in the essential oils of kaffir lime leaf, representing $89 \%$ of the total oil (Waikedre et al., 2010). The oil is rich in monoterpenes (87\%) and other minor components like B-pinene (10\%) and limonene (4.7\%). It is characterized by high content of terpinen-4-ol $(13.0 \%)$, a-terpineol $(7.6 \%), 1.8$-cineole $(6.4 \%)$, and citronellol (6.0\%). Another research finds twenty-nine compounds in the essential oils of kaffir lime leaves, and B-citronellal is the major compound amounting to $66.85 \%$ of the total oils (Loh et al., 2011). Hydrodistillation process has been used in the isolation of essential oils (Gök et al., 2015; Kusuma et al., 2017). The conventional method used for extracting essential oils from plant materials is known to have some advantages, i.e., technically simple and cheap, which warrant its feasibility to be commonly used in industrial essential oil extraction.

Steam explosion is a hydrolytic pretreatment that may release the constitutive components of biomassincreasing the enzyme and solvent accessibility of cellulose (Glasser and Wright, 1998), induce the 
breakdown of lignocellulosic structural elements by the synergism process of heating and shearing forces resulting in moisture expansion, and open the structure and increase the pore size of the cell wall. Since its early development by Mason (1928), steam explosion has been applied extensively in the conversion of biomass, such as eel grass (Viola et al., 2008), hemp (Sipos at al., 2010), Salix (Horn et al., 2011), corn stalk (Guo et al., 2010), sumac fruit (Chen and Chen, 2010), and olive leaf (Juan et al., 2016). During steaming, hemicelluloses are subjected to degradation by autohydrolysis. Pretreatment process like ultrasonic, pulsed electric field, and microwave has been extensively studied for its role in enhancing the oil yield in oil extraction from plants. Pretreatments aim to disrupt the cell wall's materials and enlarge its pore size so that the oil is discharged easily during the extraction process. However, the application of steam explosion as a pretreatment in essential oil extraction by hydrodistillation has not been reported yet. Therefore, this research aimed to compare SE-HD and Hydrodistillation (HD) processes in terms of essential oil yield, physical character, chemical composition and quality.

\section{MATERIALS AND METHODS}

\section{Plant Materials}

The samples of kaffir lime (Citrus hystrix DC) leaves were collected from a local orchard in Klaten, Central Java Province. After these samples arrived at the laboratory, the mature leaves were sorted out manually based on size and color (i.e., glossy dark green and bright green). The leaves were washed under running tap water and used in the experiments without undergoing a crushing process. The species was collected in March-April 2017.

\section{Steam Explosion Pretreatment}

The experimental unit was set up as shown in Figure 1. Three-hundred gram of fresh kaffir leaves and $33 \%$ of water in a $3 \mathrm{~L}$ reactor were heated at a temperature of $120^{\circ} \mathrm{C}-130{ }^{\circ} \mathrm{C}$ and saturated pressure of 1 bar. The explosion was achieved by the sudden release of pressure at the studied temperature. The steam explosion was carried out at a temperature of $120{ }^{\circ} \mathrm{C}-130{ }^{\circ} \mathrm{C}$ and saturated pressure of 1 bar, and the mass fraction of water was $33 \%$. The steam explosion process in this research was a modification technology from the steam explosion designed by Saeki et al. (2017).

\section{Hydrodistillation}

The hydrodistillation used a modified Clevenger apparatus. The leaf-water ratio in this research was $1: 5$, and the distillation was conducted for 2 hours. The collected essential oil was dehydrated with anhydrous sodium sulfate, flushed with nitrogen gas, kept in a colored vial, and stored at $4{ }^{\circ} \mathrm{C}$ for further analysis. The extraction process that used steam explosion pretreatment was referred to as SE-HD, while the one using untreated kaffir lime leaves was labeled with HD. The oil was analyzed for their specific gravity, refractive index, optical rotation, and appearance. The water content of fresh kaffir leaves was $72.612 \pm 0.021 \%$. The essential oil yield was calculated using the following formula (Kasuan et al., 2013; Kusuma et al., 2017).

$$
\text { Yield }\left(\%, \frac{w}{w}\right)=\frac{\text { mass of essential oil }}{\text { mass of fresh leaves } \times(1-\text { water content })} \times 100 \%
$$

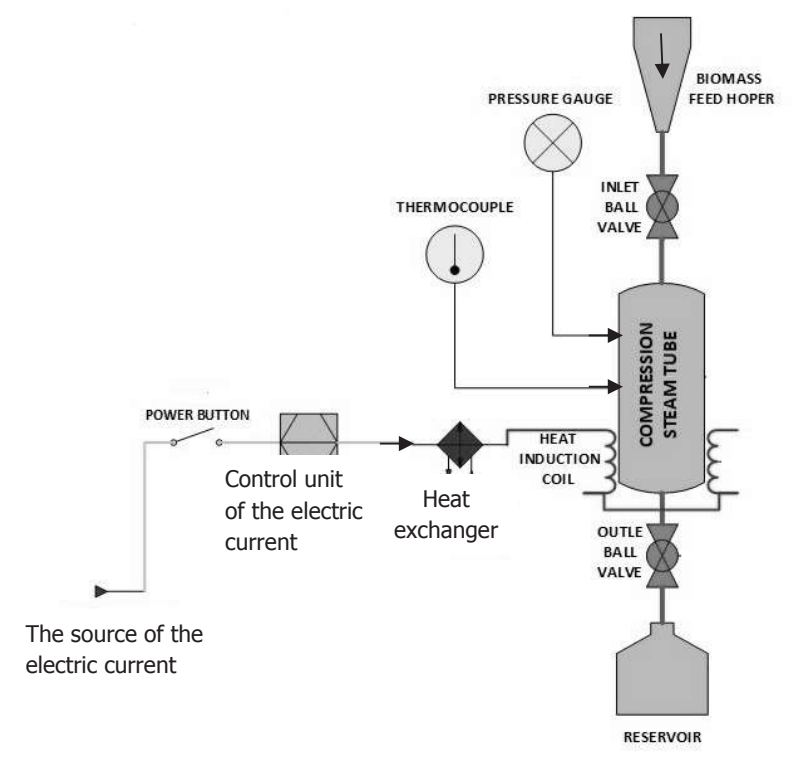

Figure 1. The experimental setup of steam explosion

\section{Chromatographic Analysis}

The chromatography analysis was performed using a gas chromatograph-mass spectrometer (SHIMADZUQP2010S) that was equipped with a fused-silica capillary column SH-Rxi-5Sil MS $30 \mathrm{~m} \times 0.25 \mathrm{~mm}$ (ID) $\times 0.25 \mu \mathrm{m}$ (film thickness). The injection temperature was $260^{\circ} \mathrm{C}$ with an injection volume of $0.3 \mu \mathrm{L}$ in the split mode (a split ratio $=10: 1$ ). The oven temperature was programmed at $40^{\circ} \mathrm{C}$ for $0.5 \mathrm{~min}$, followed by an increase of $5{ }^{\circ} \mathrm{C}$ per minute up to $250^{\circ} \mathrm{C}$. The carrier gas was Helium $(3.0 \mathrm{~mL} / \mathrm{min})$. These analyses were carried out using the Hewlett-Packard 5890A GC/MS. The mass spectra were obtained by electron ionization (EI). The temperature of the ion source was $280^{\circ} \mathrm{C}$ and 
the electron energy was $70 \mathrm{eV}$. The volatile compounds were identified by comparing their mass spectra witt the mass spectral database.

\section{Leaf Structure Conservation}

The scanning electron micrographs of Citrus hystri; leaves were captured using FEI Quanta 200. Before SEN evaluation, the samples were coated with gold usinc the plasma sputtering technique. The micrographs were carried out using a field-emission SEM (JOEL JSM-651C LA, Japan). The structures of the fracture surface wert observed under the same magnification.

\section{Statistical Analysis}

Analysis of variance (ANOVA) in a completel) randomized design, Duncan's multiple range test was performed to compare the data. All determinations were done at least in twice and all were averaged. The confidence limits used in this study were based on $95 \%$ $(p<0.05)$.

\section{RESULTS AND DISCUSSION}

\section{Essential Oil Extraction}

The yields of SE-HD and HD essential oil extraction from fresh kaffir lime leaves were $1.386 \pm 0.09 \%$ and $1.182 \pm 0.08 \%$, respectively, after 2-hour extraction (Figure 2). The extraction time for the SE-HD method was shorter than the conventional HD. The time required to achieve maximum yield was $35 \mathrm{~min}$ for the SE-HD method and 120 min for the HD method. The results revealed a substantial saving of time and energy.

Figure $2 \mathrm{a}$ and $2 \mathrm{~b}$ show that the extraction yield varies according to extraction time. There were four phases observed in this experiment. The first was the heating phase from room temperature to boiling temperature in which the first droplet of essential oil was seen. Compared to the HD method, the heating process in SE-HD required only 5 min instead of $15 \mathrm{~min}$. With this extraction time, SE-HD produced a higher oil yield $(10.46 \%)$ than HD. The steam explosion, as seen in Figure 5, could induce the breakdown of the structure of the lignocellulosic matrix in leaves (Viola et al., 2008; Juan et al., 2016). Therefore, the trapped essential oils might be removed easily from the matrices. The second phase was represented by the first exponential quantities of extracted essential oil, which accounted for approximately $80 \%$ of the total yield obtained after 25 min in the HD method and 10 min in the SE-HD method. In this step, the oil came out of the epidermis on the leaves and, transported by the steam. The third phase was indicated by the second exponential quantities of

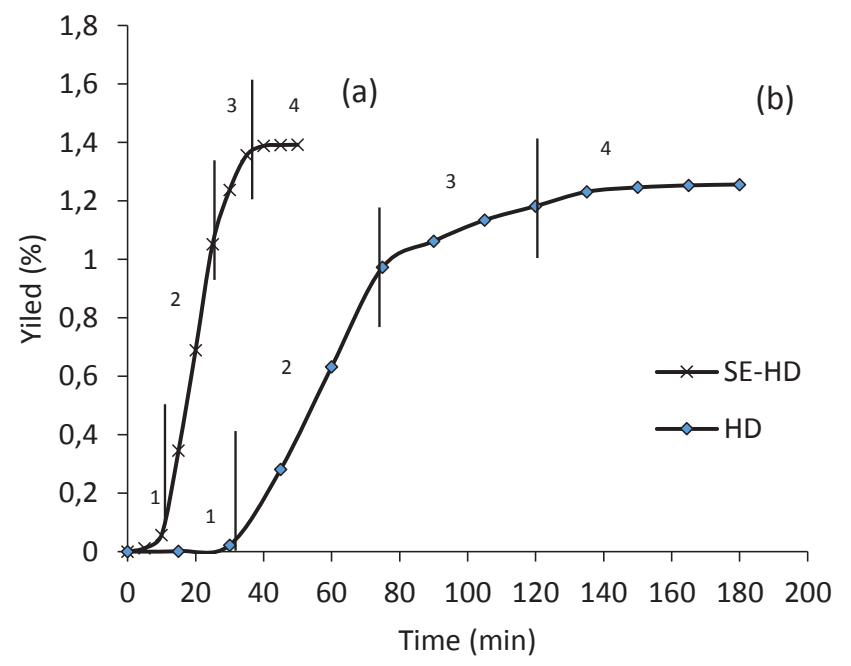

Figure 2. The yield profiles as a function of time for the essential oil extraction from fresh kaffir lime leaves using SE-HD (a) and HD (b)

extracted essential oil, which represented the internal diffusion of the essential oil from the middle of the leaf matrices to the external medium. This stage was achieved after 35 min and 120 min by SE-HD and HD, respectively. The extracted oil constituted nearly $20 \%$ of the total yield. The fourth step (step 4) was the end of the extraction processes. Since almost all of the essential oil was extracted in the previous stages, there was no additional yield observed at the final stage.

The variation of yield by extraction time was determined using kinetic modeling (Kusuma et al., 2017). According to Figure 2, the kinetic models for the extraction of kaffir lime leaf oil by SE-HD and HD methods were developed using the first- and secondorder models. The linearization of each plot of the experimental data was based on slope and intercept. From this process, the rate constant $\left(k_{1)}\right.$, extraction

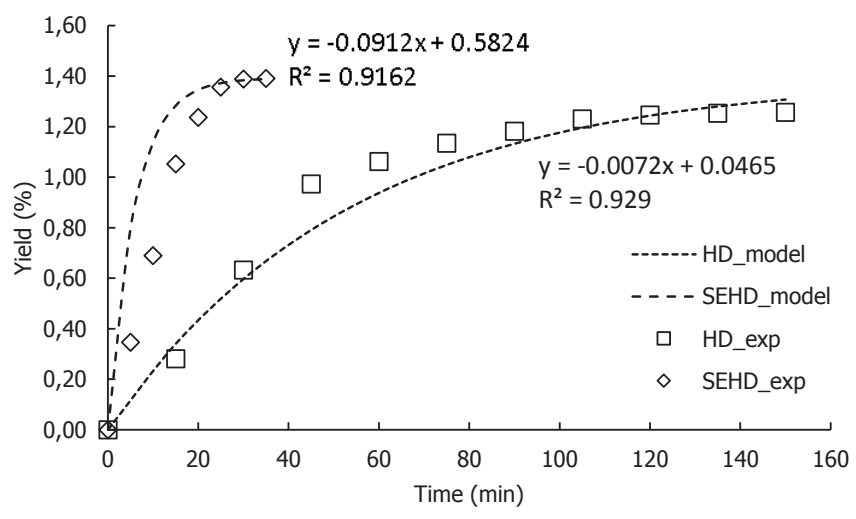

Figure 3. The linearization of the first-order kinetics of kaffir lime leaf oil 


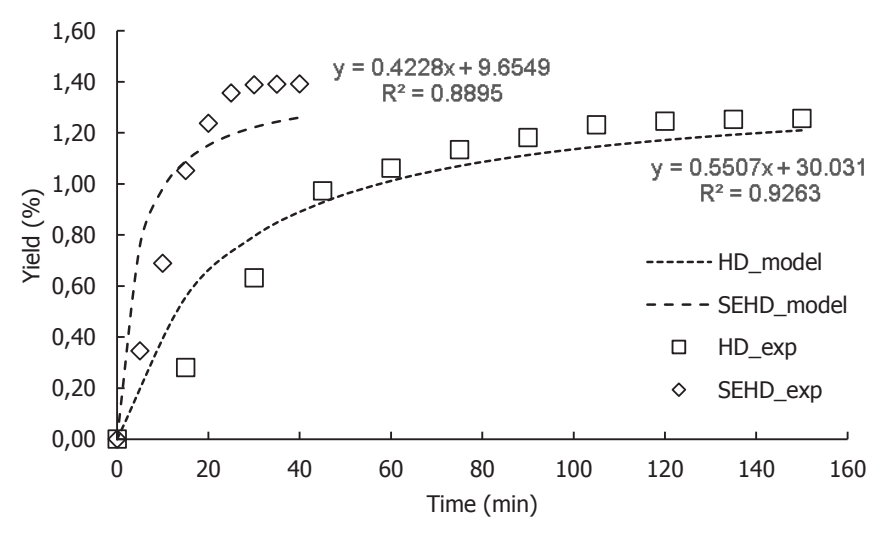

Figure 4. The linearization of the second-order kinetics of kaffir lime leaf oil

capacities $\left(C_{s}\right)$, and coefficient of determination $\left(R^{2}\right)$ for the first-order kinetic model were determined. The same data and procedure were used to determine the values of $\mathrm{k}_{2}, C_{\mathrm{s}^{\prime}}$ and $\mathrm{R}^{2}$ for the second-order kinetic model. The linearization of the first- and second-order kinetic models for the extraction of kaffir lime leaf oil using HD and SE-HD methods is shown each in Figure 3 and Figure 4.

Table 1 shows that the first-order rate constant $\left(k_{1}\right)$ for the SE-HD-assisted extraction is higher (i.e., by 9.0695 times) than the HD-assisted one. This condition indicates that SE-HD facilitates a faster oil removal than HD. This research also evaluated the experimental results from these extraction processes in the secondorder kinetic model. The $\mathrm{k}_{2}$ values of the extraction processes have the same trend as the first-order kinetic model. When compared with the HD-assisted extraction, SE-HD results in a faster rate constant of oil extraction by 5.4025 times. Therefore, the extraction of kaffir lime leaf oil using the classic HD requires longer extraction time when compared with the SE-HD method. The study results indicated SE-HD as a more favorable method for extracting the essential oil of kaffir lime leaves than HD.
Since SE-HD does not use any chemicals, this method can be considered as an environmentally friendly extraction process.

\section{The Physical Properties of Kaffir Lime Leaf Oil}

The physical properties of the essential oil extracted from kaffir lime leaves using SE-HD and HD are shown in Table 1 . The results seemed to indicate that there was no significant difference among the physical properties of SE-HD and HD essential oil, except for color. The SE-HD essential oil has a lighter color than that of HD essential oil. The characteristics of these oils are quite similar to the kaffir lime leaf oils treated with automated steam distillation process before hydrodistillation (Kasuan et al., 2013). Therefore, based on the physical properties, yield, and extraction time, the steam explosion was the appropriate pretreatment method before the hydrodistillation process for kaffir leaf oil extraction. The SE-HD-assisted extraction produces oil with favorable appearance (i.e., colorless) and high yield, and it may save the distillation time.

The quality standards for the physical properties of essential oil from kaffir lime leaves are not available yet. However, the quality standards for kaffir lime peel oil have been issued, namely, TCFF Code: 200340020. Based on the previous research (Khasanah et al., 2015), hydrodistillation with aging pretreatment for the extraction of kaffir lime leaf oil produces $0.867 \pm 0.029 \%$ of essential oil (i.e., oil yield) with the following properties: specific gravity of $0.843 \pm 0.0005$, a refractive index of $1.451 \pm 0.0001$, and an optical rotation $-13.5^{\square}$. The physical properties of the kaffir lime leaf oil in this research are nearly similar to the results of the other studies, except for the oil yield. Using SE-HD as a pretreatment has increased the oil yield by approximately 1.606 times. As a conclusion, this procedure proposed in this research yields essential oil with similar quantity but better quality than the previous studies.

Table 1. The linearization of the first- and second-order kinetic models for the extraction of kaffir lime leaf oil using HD and SE-HD method

\begin{tabular}{lllllll}
\hline Extraction methods & Slope $^{\mathrm{a}}$ & $\begin{array}{l}\text { Cs, } \\
\mathrm{g} \mathrm{L}^{-1}\end{array}$ & Intercept & $\mathrm{k}_{1}{ }^{\mathrm{a}} \mathrm{min}^{-1}$ & $\begin{array}{l}\mathrm{k}_{2 \prime} \\
\mathrm{L}^{-1} \mathrm{~min}^{-1}\end{array}$ & $\mathrm{R}^{2}$ \\
\hline $\mathrm{HD}$ & -0.0072 & 1.256 & 0.0465 & 0.0187 & - & 0.9290 \\
$\mathrm{SE}-\mathrm{HD}$ & -0.0912 & 1.392 & 0.5824 & 0.1696 & - & 0.9162 \\
HD & 0.5507 & 1.256 & 30.0310 & - & 0.0318 & 0.9263 \\
SE-HD & 0.4228 & 1.392 & 9.6549 & - & 0.1718 & 0.8895 \\
\hline
\end{tabular}

aalues generated from the feature Trendlines in Microsoft Excel (see Figure 3 and 4) 


\section{The Characteristics of the Volatile Compounds of Essential Oils}

The chromatograms of SE-HD and HD essential oils are similar (Figure 5 and Figure 6) with citronellal (peak number 9 ) as the most prominent compound (i.e., over $70 \%$ of total chromatogram), followed by citronellyl acetate, citronellol, linalool, geranyl acetate, nerolidol, and other compounds with small concentration. In this study, the application of steam explosion as a treatment before the hydrodistillation process, which may profoundly accelerate the extraction process, did not cause any considerable changes in the volatile oil composition (Table 2). The presence of citronellal as the main component is also reported in many previous studies (Loh et al., 2011; Khasanah et al., 2015; Li et al., 2011). There were five groups observed in both SE-HD and HD essential oil. Monoterpenes were the most abundant volatile compounds in kaffir lime leaf oil from the HD and SE-HD extraction-contributing to $70 \%$ of the total volatile content, followed by esters $(15 \%)$, acid $(5 \%)$, phenol $(5 \%)$, and alkaloid (5\%). The terpenoids contained in the kaffir lime leaf oil were monoterpene hydrocarbons ( $B$-phellandrene, $B$-pinene, trans- $\beta$-ocimene), monoterpene alcohol (cis linalool, trans-linalool oxide, Linalool, Citronellol), oxygenated monoterpenes (Citronellal, Isopulegol), cyclic monoterpenes (3-cyclohexane-1-ol), sesquiterpenes (Cadinene, Nerolidol), and sesquiterpene hydrocarbons ( $\mathrm{Y}$-terpinene, B-caryophyllene). Furthermore, this research found three esters in the volatile constituents (citronellyl acetate, neryl acetate, geranyl acetate), one acid (octadecanoic acid), one phenol (eugenol), and one alkaloid (pyridine) were considered.

The major constituents of the volatile compounds of kaffir lime leaf oils, which are presented in Table
Table 2. The physical properties of the essential kaffir lime leaf oil extracted with SE-HD and HD

\begin{tabular}{lll}
\hline Physical properties & Essential oils & \\
& SE-HD & HD \\
\hline Specific gravity $\left(22^{\circ} \mathrm{C}\right)$ & $0.855 \pm 0.12^{\text {ns }}$ & $0.848 \pm 0.23^{\text {ns }}$ \\
Refractive index $\left(25^{\circ} \mathrm{C}\right)$ & $1.447 \pm 0.13^{\text {ns }}$ & $1.445 \pm 0.14^{\text {ns }}$ \\
Optical rotation in degree & $-12.5 \pm 0.00$ & $-12.5 \pm 0.00$ \\
Appearance & Colorless & Pale \\
\hline
\end{tabular}

Column with different letters represents a significant difference ( $p$ $<0.05$, ns: not significant)

3, are also found in other essential oils. Monoterpene hydrocarbon like $B$-phellandrene is a major compound found in oils extracted from Curcuma longa roots and rhizomes (Li et al., 2011). This compound is also found in coriander and lemon essential oils with potent bioactivity as insecticide and antimicrobial (Teixeira et al., 2013). Trans- $\beta$-ocimene is also found in the flower, peel, and leaf of some citrus species (e.g., mandarin, orange, and pummelo). Ocimenes can change into 2,6-dimethyl3,5,7-octatriene-2-ol, Z,Z- because of oxidation process (Sonwa et al., 2007). Ocimenes are also found in the spice ajwain (Trachyspermum ammi) with some potential bioactivities, such as anti-inflammatory, anticancer, antibacterial, antitumor, insecticide, sedative, pesticide, herbicide, immunomodulator, fungistat, antiobesity, and seasoning 3-cyclohexane-1-ol is a cyclic monoterpene compound found in Citrus limetta (Juáréz et al., 2012). B-caryophyllene and nerolidol are also found in the essential oil of cinnamon (Cinnamomum osmophloeum) twigs, and they exhibit excellent anti-inflammatory activity (Tung et al., 2008). Isopulegol is a monoterpene compound with a fresh green odor (Paramasari, 2017).

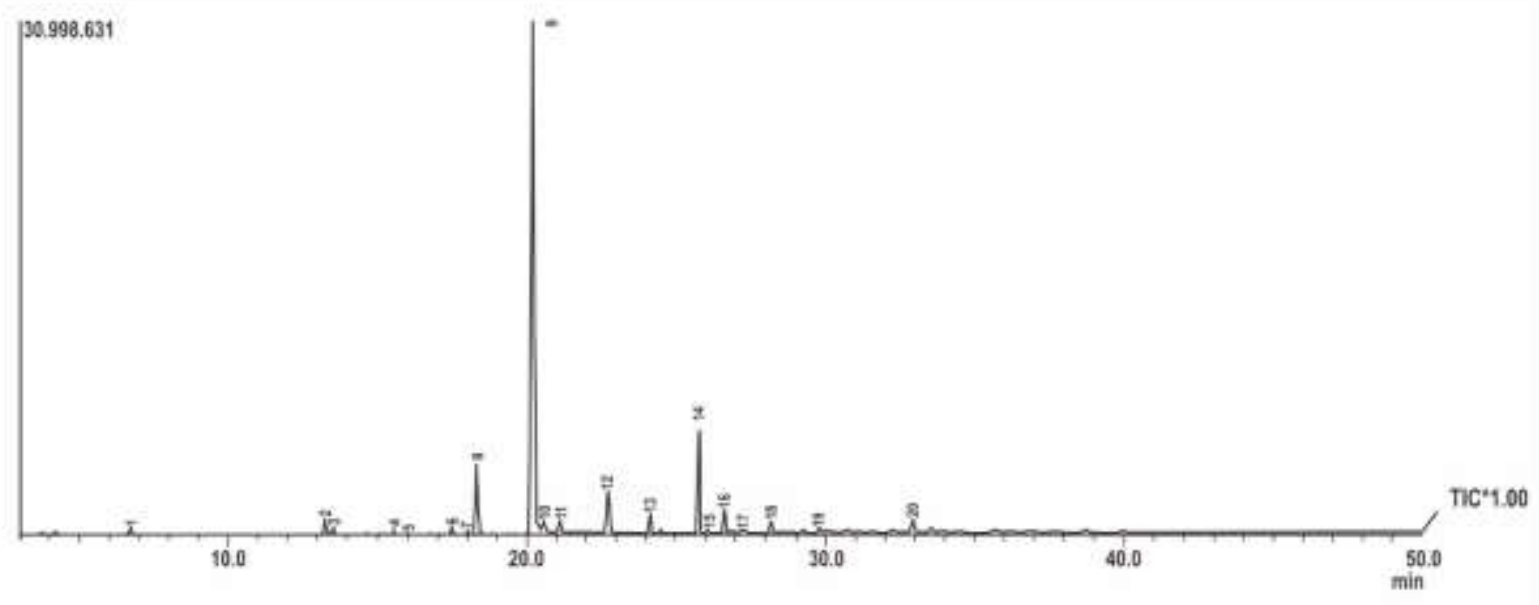

Figure 5. The GC-MS Chromatogram of kaffir lime leaf oil obtained by SE-HD 


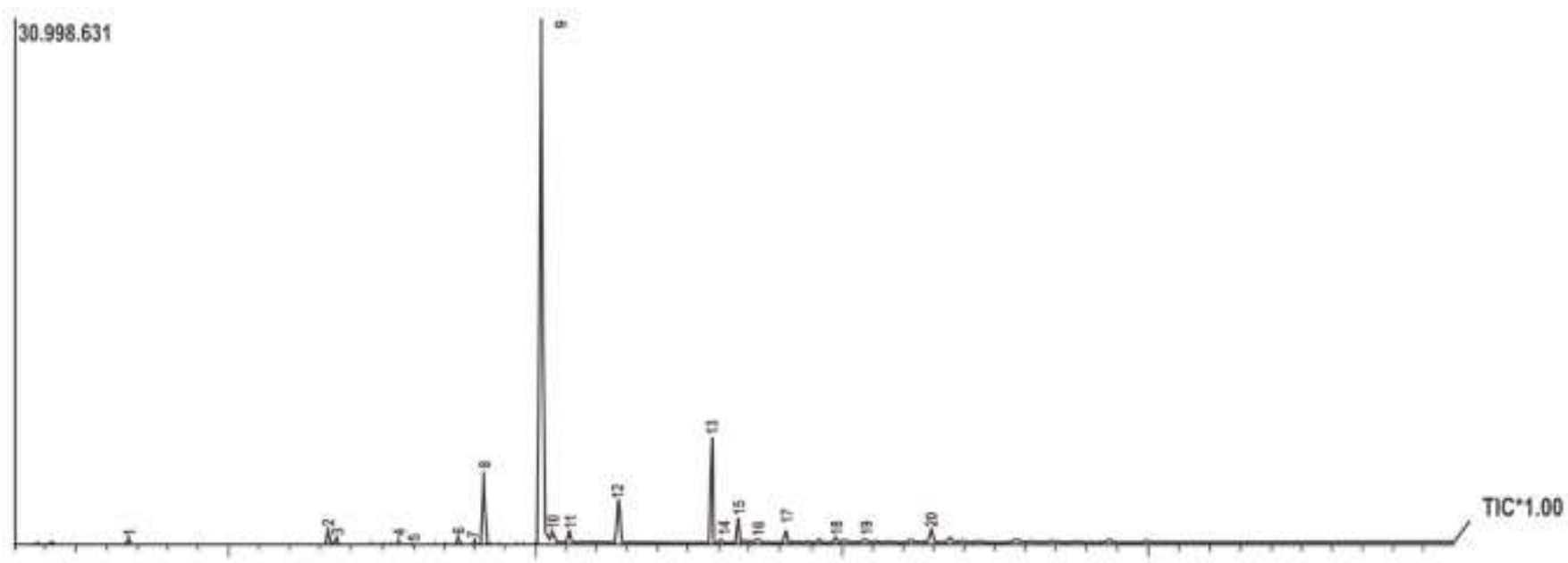

Figure 6. The GC-MS Chromatogram of kaffir lime leaf oil obtained by HD

Esters are considered as a key aroma constituent because they impart a fruity aroma. Esters like citronellyl acetate create many types of fruity and floral scents and, therefore, they are suitable as flavor ingredients.

\section{The Leaf Structure of Kaffir Lime Leaves}

Kaffir lime leaves constitute biomass of lignocellulosic composition, a complex mixture of cellulose, hemicelluloses, and lignin. Steam explosion pretreatment allows the breakdown of biomass components by steam heating and shearing forces due to the concomitant expansion. The sudden decompression, which terminates the reaction, decreases the temperature rapidly and, therefore, damages the particulate structure of kaffir lime leaves. The distinct physical change of SE-HD and HD kaffir lime leaves is shown in Figure 5a-c.

Table 3. The characteristics of the volatile compounds of kaffir lime essential oil extracted with SE-HD and HD

\begin{tabular}{|c|c|c|c|c|c|c|}
\hline \multirow{2}{*}{$\begin{array}{l}\text { Peak } \\
\text { no. }\end{array}$} & \multirow{2}{*}{ Compounds } & \multirow{2}{*}{$\mathrm{T}_{\mathrm{r}}(\min )$} & \multicolumn{2}{|c|}{$\%$ Relative peak area } & \multirow{2}{*}{ *ref } & \multirow{2}{*}{ Odor characteristics } \\
\hline & & & SE-HD & $\mathrm{HD}$ & & \\
\hline 1 & Pyridine & 6.738 & 0.40 & 0.35 & - & \\
\hline 2 & B-phellandrene & 13.231 & 1.02 & 1.77 & $\left.\left.{ }^{a}\right), b\right)$ & Terpeny, fruity, minty, herbaceous \\
\hline 3 & B-pinene & 13.531 & 0.50 & 0.75 & $\left.\left.\left.{ }^{a}\right),{ }^{b}\right),{ }^{c}\right)$ & $\begin{array}{l}\text { Musty, green, sweet, pine-resin } \\
\text { like, pungent (turpentine), woody }\end{array}$ \\
\hline 4 & Trans-ß-ocimene & 15.537 & 0.47 & 0.56 & $\left.\left.{ }^{a}\right),{ }^{b}\right)$ & $\begin{array}{l}\text { Herbaceous, mild,typical odor of } \\
\text { citrus, orange, or lemon }\end{array}$ \\
\hline 5 & Cadinene & 29.809 & 0.25 & 0.18 & b) & Herbaceous, woody \\
\hline 6 & Nerolidol & 32.907 & 1.30 & 1.43 & c) & Waxy \\
\hline 7 & y-terpinene & 16.003 & 0.12 & 0.13 & $\left.\left.\left.{ }^{a}\right),{ }^{b}\right),{ }^{c}\right)$ & $\begin{array}{l}\text { Citrus-like, herbaceous, fruity, } \\
\text { sweet }\end{array}$ \\
\hline 8 & B-caryophyllene & 28.175 & 0.81 & 0.31 & $\left.\left.{ }^{e}\right),{ }^{c}\right),{ }^{d}$ ) & Oily, fruity, woody \\
\hline 9 & Cis linalool & 17.456 & 0.54 & 0.60 & - & \\
\hline 10 & Trans-linalool oxide & 18.015 & 0.26 & 0.28 & b) & Fresh, green, fruity \\
\hline 11 & Linalool & 18.317 & 5.07 & 4.94 & $\left.\left.\left.{ }^{b}\right),{ }^{c}\right),{ }^{d}\right)$ & $\begin{array}{l}\text { Green, floral, sweet, the typical } \\
\text { odor of lemon or lavender }\end{array}$ \\
\hline 12 & Citronellol & 22.704 & 4.93 & 5.79 & $\left.\left.\left.{ }^{a}\right),{ }^{f}\right),{ }^{g}\right)$ & Sweet, citrus-like \\
\hline 13 & Citronellal & 20.223 & 72.26 & 70.99 & $\left.\left.{ }^{a}\right),{ }^{f}\right),{ }^{g}$ ) & Citrus-like \\
\hline
\end{tabular}




\begin{tabular}{|c|c|c|c|c|c|c|}
\hline \multirow{2}{*}{$\begin{array}{l}\text { Peak } \\
\text { no. }\end{array}$} & \multirow{2}{*}{ Compounds } & \multirow{2}{*}{$\mathrm{T}_{\mathrm{r}}(\min )$} & \multicolumn{2}{|c|}{$\%$ Relative peak area } & \multirow{2}{*}{ *ref } & \multirow{2}{*}{ Odor characteristics } \\
\hline & & & SE-HD & $\mathrm{HD}$ & & \\
\hline 14 & Isopulegol & 20.555 & 1.31 & 0.88 & i) & Fresh green \\
\hline 15 & Citronellyl acetate & 25.769 & 6.87 & 0.20 & $\left.\left.\left.{ }^{a}\right),{ }^{f}\right),{ }^{g}\right)$ & Citrus-like, oily \\
\hline 16 & Neryl acetate & 26.096 & 0.18 & 1.55 & - & \\
\hline 17 & Geranyl acetate & 26.630 & 1.51 & 0.18 & - & \\
\hline 18 & 3-cyclohexen-1-ol & 21.107 & 0.87 & 0.73 & - & \\
\hline 19 & Octadecanoic acid & 24.128 & 1.23 & 7.33 & - & \\
\hline 20 & Eugenol & 27.230 & 0.11 & 1.06 & g) & Herbaceous \\
\hline
\end{tabular}

*The reference are obtained from previous studies. a) Gonçalves et al., (2014), b) Choi (2003), c) Njoroge et al., (1994), d) Choi and Sawamura, (2000), e) Sato et al., (1990), f) Tung et al., (2008), g) Paramasari (2017), i) Juáréz et al.., (2012)

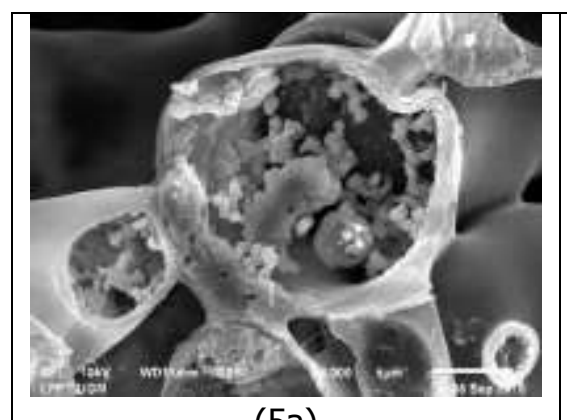

(5a)

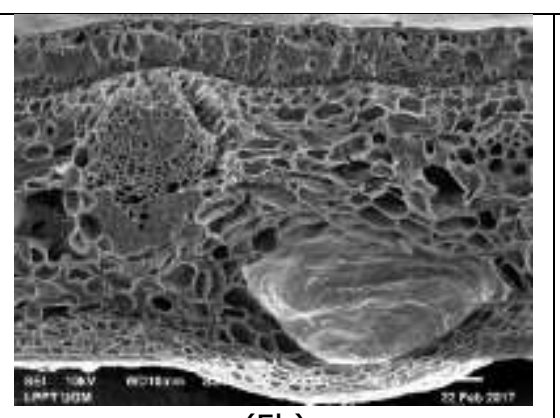

$(5 b)$

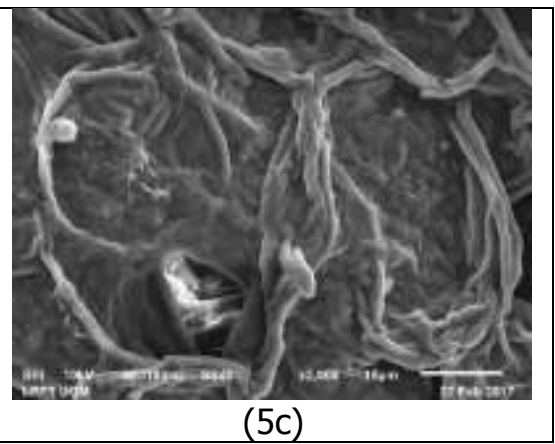

(5c)

Figure 5. The scanning electron micrograph of kaffir lime leaves: (a) untreated, (b) after hydrodistillation and (c) after steam explosion-hydrodistillation

The micrograph of the untreated leaves (Figure $5 a)$ shows that the cell structures differ somewhat significantly from the treated leaves, as presented in Figure $5 b(\mathrm{HD})$ and $5 c \mathrm{SE}-\mathrm{HD})$. The structure of the untreated kaffir lime leaves (Figure 5a.) clearly show that the shape of the glandular cells is rigid and that their volatile oils are still intact. Figure $5 b$ shows that after HD extraction, the glandular cell is empty and collapsed, the essential oil is completely discharged, but the cell is still intact. Figure $5 c$ shows that the SE-HD kaffir lime leaves processed by a combination of steam explosion and hydrodistillation suffer massive damage not only on their external surface but also on their internal surface (e.g., the cellular materials). These findings indicate that steam explosion makes the glandular cell disintegrate or rupture more rapidly and efficiently, which is similar to the previous research that employs steam explosion for the extraction of sugars and natural antioxidants from olive leaves (Juan et al., 2016). The cellular damage in kaffir lime leaves makes the oil flow out quickly from the cell and, thereby, shortens the distillation time, as shown in Figure 2. As a result, the essential oil in this study was removed at a fast rate from the glandular cells.

\section{CONCLUSIONS}

Steam explosion pretreatment causes the kaffir lime leaf cell to collapse and rupture. It reduces the extraction time, resulting in the same quality as the untreated kaffir lime leaves but with a higher yield (i.e., by $17.258 \%$ ) than the conventional hydrodistillation. Therefore, SE-HD is recommended as an excellent alternative method for the extraction of essential oils. Furthermore, as an extraction method, it has many favorable characters, namely fast, modern, and environmentally friendly.

\section{ACKNOWLEDGMENTS}

This research was supported by the Doctoral Dissertation Research Grant funded by the Indonesian Ministry of Research, Technology, and Higher Education in 2017. 


\section{CONFLICT OF INTEREST}

Authors declare that there was no conflict interest between authors and the founder.

\section{REFERENCES}

Butryee, C., Sungpuang, P., \& Chitchumroonchokchaic. (2009). Effect of processing on the flavonoid content and antioxidant capacity of Citrus hystrix leaf. International Journal of Food Sciences and Nutrition, 60. http://doi. org/10.1080/09637480903018816

Chen, G., \& Chen, H. (2010). Enhancement of oil extraction from sumac fruit using steam-explosion pretreatment. Journal of the American Oil Chemists'Society, 88. http:// doi.org/10.1007/s11746-010-1650-6

Choi, H. S. (2003). Character impact odorants of Citrus Hallabong $[(C$. Unshiu Marcov $\times$ C. Sinensis Osbeck $) \times C$. reticulataBlanco] cold-pressed peel oil. Journal of Agricultural Food Chemistry, 51. http://doi.org/1021/ jf021069o

Choi, H. S., \& Sawamura, M. (2000). Composition of the essential oil of Citrus tamurana Hort. Ex Tanaka (Hyuganatsu). Journal of Agricultural Food Chemistry, 48. http://doi.org/10.1021/jf000651e

Chueahongthong, F., Ampasavate, C., Okonogi, S., Tima, S., \& Anuchapreeda, S. (2011). Cytotoxic effects of crude kaffir lime (Citrus hystrix DC.) leaf fractional extracts on leukemic cell line. Journal of Medical Plant Research, 5(4), 3097-3105.

Glasser, W. G., \& Wright, R. S. (1998). Steam-assited biomass fractionation. II. Fractionation behavior of various biomass resources. Biomass Bioenergy, 14. http://doi. org/10.1016/S0961-9534(97)10037-X

Gök, A., Kirbaşlar, I., \& Kirbaşlar, F. G. (2015). Comparison of lemon oil composition after using different extraction methods. Journal of Essential Oil Research, 27. http:// doi.org/10.1080/10412905.2014.982872

Gonçalves, J., Figueira, A. J., Rodrigues, F. P., Ornelas, P. L., Branco, R. N., Silva, C. L., \& Câmara, J. S. (2014). A powerful methodological approach combining headspace solid phasemicroextraction, mass spectrometry and multivariate analysis for profiling the volatile metabolomic pattern of beer starting raw materials. Food Chemistry, 160. http://doi.org/10.1016/j.foodchem.2014.03.065

Guo, P., Monchidzuki, K., Cheng, W., Zhou, M., Gao, H., Zheng, D. X., Wang \& Cui, Z. (2010). Effects of different pretreatment strategies on corn stalk acidogenic fermentation using a microbial consortium. Bioresource Technology, 102. http://doi.org/10.1016/j. biotech.2011.04.083

Horn, S. J., Estevez, M. M., Neilson, H. K., Linjordet, R., Vincent, G. H., \& Eijsink. (2011). Biogas production and saccharification of Salix pretreated at different steam explosion conditions. Bioresource Technology, 102. http://doi.org/10.1016/j.biortech.2011.06.042

Juan, M. R. G., Antonio, L. M., Guillermo, R. G., Manuel, M., Encarnacion, R., Juan, F. B., \& Eulogio, C. (2016). Obtaining sugars and natural antioxidants from olive leaves by steam-explosion. Food Chemistry, 210. http:// doi.org/10.1016/j.foodchem.2016.05.003

Juáréz, M. C. C., Nunez, R. E. R., Ălvarez, J. E. B., Gonzáles, G. M. M., Bolańos, J. L. N., \& Islas, H. J. (2012). Characterization of volatile compounds in the essential oil of sweet lime (Citrus limetta Risso). Chilean Journal of Agricultural Research, 72 (2), 275-280.

Kasuan, N., Muhammad, Z., Yusuoff, Z., Rahiman, M. H. F., Taib, M. N., \& Haiyee, Z. A. (2013). Extraction of citrus hystrix d.c. (kaffir lime) essential oil using automated steam distillation process: analysis of volatile compounds. Malaysian Journal of Sciences, 17(3), 359-369.

Kawiji, Khasanah, L. U., Rohula, U., \& Aryani, N. T. (2015). Ekstraksi maserasi oleoresin daun jeruk purut (Citrus hystrix DC): optimasi rendemen dan pengujian karakteristik mutu. Agritech, 35(2), 178-184. http://doi. org/10.22146/agritech.13761

Khasanah, L. U., Kawiji, Rohula, U., \& Aji, Y. M. (2015). Pengaruh perlakuan pendahuluan terhadap karakteristik mutu minyak atsiri daun jeruk purut (Citrus hystrix $D C$ ). Jurnal Aplikasi Teknologi Pangan 4(2), 48-55.

Kusuma, H. S., Rohadi, T. I, Daniswara, E. F., Altway, A., \& Mahfud, M. (2017). The extraction of essential oils from patchouli leaves (Pogostemon cablin Benth) using a microwave air-hydrodistillation method as a new green technique. RCS Advances, 3, 1336-1347.

Li, S., Yuan, W., Deng, G., Wang, P., \& Yang, P. (2011). Chemical composition and product quality control of turmeric (Curcuma longa L.). Pharmaceutical Crops, 2, 28-54.

Loh, F. S., Awang, R. M., Omar, D., \& Rahmani, M. (2011). Insecticidal properties of citrus hystrix dc leaves oil against spodoptera liture fabricius. Journal of Medical Plant Research, 5(16), 3739-3744.

Mason, W. H. (1928). Apparatus for and process of explosion fibration of lignocellulose material. US Patent, 1.655.618.

Njoroge, S. M., Ukeda, H., Kusunose, H., \& Sawamura, M. (1994). Volatile components of the essential oils from kabosu, daidai, and yuko, japanese sour citrus fruits. Journal Flavour Fragrance, 9. http://doi.org/10.1002/ ffj. 2730090603

Paramasari, I. (2017). The Volatile Compounds and Odor Characters of Tom Yum Paste. Yogyakarta: Universitas Gadjah Mada.

Ratseewo, J., Tangkhawanit, E., Meeso,N., Kaewseejan,N., \& Siriamornpun, S. (2016). Changes in antioxidant properties and volatile compounds of kaffir lime leaf 
as affected by cooking processes. International Food Research Journal, 23(1), 188-196.

Saeki, T., Hisayuki, K., Daiomon, H., \& Fujie, K. (2017). Recovery of valuable substances from unused potatoes using a steam explosion reaction. Journal of the Japan Society of Waste Management Experts, 18. http://doi. org/10.3985/jswme.18.1

Sato, A., Asano, K., \& Sato, T. (1990). The chemical composition of Citrus hystrix DC (Swangi). Journal Essential Oil Research, 2. http://doi.org/10.1080/10412905.1990.96 97857

Sipos, B., Kreuger, E., Svensson, S., Réczey, K., Björnsson \& Zacchi, G. (2010). Steam pretreatment of dry and ensiled industrial hemp for ethanol production. Biomass Bioenergy, 34. http://doi.org/10.1016/j. biombioe.2010.07.003

Siripongvutikorn, S., Thummaratwasik, P., \& Huang, Y. (2005). Antimicrobial and antioxidation effects of Thai seasoning, Tom-Yum. LWT-Food Science and Technology, 38. http:// doi.org/10.1016/j.Iwt.2004.06.006

Sonwa, M. M., Kost, C., Biedermann, A., Wegener, R., Schulz, S., \& Boland, W. (2007). Dehydrogenation of ocimene by active carbon: artefact formation during headspace sampling from leaves of Phaseolus lunatus. ARKIVOC, 3. http://doi.org/10.3998/ark.5550190.0008.315
Teixeira, B., Marques, A., Ramos, C., Neng, N. R., Nogueira, J. M. F., Saraiva, J. A., \& Nunes, M. L. (2013). Chemical composition and antibacterial and antioxidant properties of commercial essential oil. Industrial Crops and Products, 43. http://doi.org/10.1016/j.indcrop.2012.07.069

Tung, Y. T., Chua, M. T., Wang, S. Y., \& Chang, S. T. (2008). Anti-inflammation activities of essential oil and its constituents from indigenous cinnamon (Cinnamomum osmophloeum) twigs. Bioresource Technology, 99. http://doi.org/10.1016/j.biortech.2007.7.050

Viola, E., Cardinale, M., Santarcangelo, R., Villone, A., \& Zimbardi. (2008). Ethanol from eel grass via steam explosion and enzymatic hydrolysis. Biomass Bioenergy, 32. http://doi.org/10.1016/i.biombioe.2007.12.009

Waikedre, J., Dugay, A., Barrachina, I., Herrenknecht, C., Cabalion, P., \& Fournet, A. (2010). Chemical composition and antimicrobial activity of the essential oils from new caledonian citrus macroptera and citrus hystric. Chemistry \& Biodiversity, 7. http://doi.org/10.1002/ cbdv.200900196 